\title{
NAČELO ZAŠTITE LEGITIMNIH OČEKIVANJA U UPRAVNOM PRAVU EUROPSKE UNIJE I PRAVNA AUTONOMIJA DRŽAVA ČLANICA
}

Sažetak: $\quad$ Zaštita legitimnih očekivanja opće je načelo prava Europske unije koje se razvilo kroz praksu Suda Europske unije. Analiza te prakse ukazala je na više otvorenih pitanja koja uključuju, među ostalim, kada je zakonodavac Europske unije vezan legitimnim očekivanjima stranaka koje je stvorilo prethodno, u međuvremenu izmijenjeno, zakonodavstvo Unije; u kojim situacijama prethodna upravna praksa stvara legitimna očekivanja; nelegitimnost očekivanja koja su nastala $u$ spekulativne svrhe; razliku u pravnoj snazi protupravnih upravnih odluka i drugih postupanja uprave za nastanak legitimnih očekivanja. Također se postavilo pitanje odnosa prava Europske unije i autonomije država članica, vezano uz mogućnost da nezakoniti upravni akti stvore legitimna očekivanja te istek nacionalnog zakonskog roka za ukidanje nezakonitog rješenja kojim je stranka stekla neko pravo, u kojem slučaju se država članica ne može pozivati na nacionalna pravila upravnog postupka zbog povrede načela djelotvornosti prava Europske unije. Cilj ovog rada je analizirati navedena pitanja te utvrditi može li se regulatorni okvir Europske unije unaprijediti kako bi se izbjegli problemi u praksi koji se mogu pojaviti. U analizi se koristi praksa Suda Europske unije i pravni akti Europske unije te domaća i strana literatura iz područja upravnog, ustavnog i europskog prava.

Opisani problemi ilustriraju manjkavost trenutačnog pravnog uređenja Europske unije s mnoštvom pravnih izvora te ukazuju na potrebu kodifikacije upravnog postupka pred tijelima Unije. Dosad je bilo više inicijativa za kodifikacijom, no bez uspjeha, mada pravna osnova u Ugovoru o funkcioniranju Europske unije postoji. Svakako bi buduća zakonodavna rješenja na razini Unije trebala jasno isključiti mogućnost da nezakoniti upravni akti stvaraju legitimna očekivanja. Na taj način ne bi postojao ni različiti tretman nezakonitih nacionalnih upravnih odluka koje praktički ne mogu stvoriti legitimna očekivanja. Također bi trebalo izbjegavati nejasne i gotovo arbitrarne situacije, poput isključenja legitimnosti očekivanja koja su nastala u spekulativne svrhe, budući da nije jednostavno definirati kriterije kada je nešto spekulacija, a kada je legitimno korištenje promjene pravnog okvira

* Dr. sc. Tomislav Sokol, naslovni docent Hrvatskog katoličkog sveučilišta, viši predavač Zagrebačke škole ekonomije i managementa, Jordanovac 110, 10000 Zagreb, Republika Hrvatska. Adresa e-pošte: tsokol@zsem.hr. ORCID: http://orcid. org/0000-0002-3592-2967. 
na tržištu. Trebalo bi svakako izbjegavati različite kriterije u različitim područjima za koje ne postoji osnova u osnivačkim ugovorima.

Ključne riječi: $\quad$ pravna autonomija država članica, legitimna očekivanja, opća načela prava, Sud Europske unije, upravni akt, upravno pravo Europske unije

\section{UVOD}

U pravnim sustavima mnogih država, kao i onom Europske unije, sve više dolazi do izražaja relativno manje poznato načelo upravnog prava - načelo zaštite legitimnih očekivanja. ${ }^{1} \mathrm{Za}$ zaštitu legitimnih očekivanja obično se koriste dva glavna opravdanja. Prvo opravdanje temelji se na filozofiji Immanuela Kanta i potrebi zaštite razumnih očekivanja kao nužne za održavanje povjerenja u zajednici i zaštite pojedinca, budući da povreda nečijih razumnih očekivanja uzrokuje destabilizaciju i demoralizaciju te osobe. Ovakav pristup posebno je bitan u kontekstu ugovornog prava. Drugo opravdanje temelji se na odanosti, budući da poštovanje nečijih razumnih očekivanja označava odanost toj osobi, što se dalje može ekstrapolirati na šire društvene odnose. ${ }^{2} \mathrm{U}$ onom trenutku u kojem razumna očekivanja stječu pravnu utemeljenost, bez obzira na pravni izvor, može se govoriti o legitimnim očekivanjima. ${ }^{3}$

Načelo zaštite legitimnih očekivanja prvo je definirano u njemačkom upravnom pravu. S vremenom, ono se proširilo i na druge europske pravne sustave, a posebnu je važnost dobilo kao jedno od općih načela prava Europske unije, kroz praksu Suda Europske unije. ${ }^{4}$ Važno je napomenuti da ovo načelo utječe na rješavanje u upravnim stvarima od strane nadležnih tijela Europske unije, ali i na upravne akte koje donose tijela država članica u predmetima u kojima se primjenjuju materijalne norme prava EU-a, poput državnih potpora. U tom smislu, postavlja se pitanje odnosa prava EU-a i država članica, odnosno autonomije država članica da vlastitim pravnim normama uređuju način zaštite legitimnih očekivanja unutar ograničenja koje postavlja europsko pravo. Cilj ovog rada je analizirati navedeno pitanje te utvrditi može

1 Vidi Đerđa, D., Zaštita legitimnih očekivanja u upravnom pravu, Zbornik Pravnog fakulteta Sveučilišta u Rijeci, god. 34, br. 1, 2013., str. 83.

2 Vidi Barak-Erez, D., The Doctrine of Legitimate Expectations and the Distinction between the Reliance and Expectation Interests, European Public Law, god. 11, br. 4, 2005., str. 588.-589.

3 Đerđa, op. cit. u bilj. 1, str. 84.

4 Vidi čl. 48.-49. Zakona o općem upravnom postupku (Verwaltungsverfahrensgesetz, Bundesgesetzblatt, I, 2003, S. 102); Đerđa, op. cit. u bilj. 1, str. 84.-85.; Spojene Predmete 7/56 i 3/57 do 7/57 Dineke Algera, Giacomo Cicconardi, Simone Couturaud, Ignazio Genuardi, Félicie Steichen v Common Assembly of the European Coal and Steel Community [1957] ECR 00039 i Predmet 84/78 Ditta Angelo Tomadini Snc v Amministrazione delle finanze dello Stato [1979] ECR 01801 točka 25. Općenito o zaštiti legitimnih očekivanja u upravnom pravu Europske unije, vidi Craig, P., de Burca, G., EU Law: Text, Cases and Materials, Oxford University Press, Oxford, 2015., str. 558.-563.; Schwarze, J., European Administrative Law: Revised First Edition, Sweet \& Maxwell, London, 2006., str. 870.-873. Ovim načelom sve više se bavi i pravna znanost u Hrvatskoj. Vidi, primjerice, Šikić, M., Ofak, L., Nova načela upravnog postupka (s posebnim naglaskom na razmjernost, legitimna očekivanja i stečena prava), Zbornik Pravnog fakulteta Sveučilišta u Rijeci, god. 32, br. 1, 2011., str. 127.-153.; Šikić, M., Zaštita pravne sigurnosti stranaka u upravnom postupku pravomoćnost i legitimna očekivanja, Zbornik Pravnog fakulteta Sveučilišta u Rijeci, god. 35, br. 1, 2014., str. 147.-161.; Vezmar Barlek, I., Primjena načela legitimnih očekivanja u praksi Upravnog suda Republike Hrvatske, Zbornik Pravnog fakulteta Sveučilišta u Rijeci, god. 32, br. 1, 2011., str. 569.-581. 
li se regulatorni okvir Europske unije unaprijediti kako bi se izbjegli problemi u praksi koji se mogu pojaviti.

U drugom poglavlju nakon uvoda objašnjava se pojam općih načela prava Europske unije, uz poseban naglasak na njihov povijesni razvoj te trenutačni status kao izvora prava EU-a. Nakon toga, analiziraju se pretpostavke za primjenu načela zaštite legitimnih očekivanja, prvenstveno kroz praksu Suda Europske unije vezanu uz upravne odluke tijela EU-a. U idućem poglavlju obrađena je pravna autonomija država članica u području zaštite legitimnih očekivanja te ograničenja koja toj autonomiji predstavlja pravni okvir EU-a, zajedno s praktičnim problemima koji se mogu javiti u praksi zbog navedenih ograničenja. Naposljetku, daju se određene preporuke za modifikaciju postojećeg pravnog uređenja, kako bi se mogli izbjeći opisani problemi u praksi.

\section{PRAVNI IZVORI}

Nemoguće je razumjeti položaj načela zaštite legitimnih očekivanja u pravu Europske unije bez prethodnog objašnjenja njegova pravnog temelja kroz praksu Suda Europske unije (kako mu je današnji naziv) o općim načelima prava. Isti zaključak može se primijeniti i na pitanje autonomije država članica unutar okvira prava EU-a. Kroz praksu vezanu uz opća načela prava, Sud je postavio osnove za pravni okvir uređenja temeljnih ljudskih prava u sustavu EU-a, kako materijalnih, tako postupovnih. Naravno, budući da su ljudska prava temelj pravnih sustava suvremenih europskih država, ${ }^{5}$ kroz njihovo uređenje na razini Unije određena su i ograničenja slobode država članica da samostalno reguliraju izuzetno važna područja suvremenog života.

Temeljna prava u početku europske integracije nisu bila obuhvaćena osnivačkim ugovorima. Ovo se može smatrati logičnim, budući da je početni naglasak bio na stvaranju zajedničkog tržišta, utemeljenom na slobodi kretanja roba, radnika, usluga, poslovnog nastana i (u tada ograničenoj mjeri) kapitala, dok je pitanje temeljnih prava bilo u primarnoj nadležnosti Vijeća Europe. ${ }^{6}$ U tom smislu, i Sud Europske unije otklonio je mogućnost pozivanja na temeljna prava i opća načela prava općenito u kontekstu europske integracije. ${ }^{7}$ Stvari su se bitno promijenile uspostavom načela nadređenosti prava EU-a nacionalnim pravnim sustavima $u$ presudi Costa v ENEL. ${ }^{8} \mathrm{U}$ ovoj presudi Sud je utvrdio kako slijedi:

5 Vidi, primjerice, Yourow, H. C., The Margin of Appreciation Doctrine in the Dynamicy of European Human Rights Jurisprudence, Kluwer Law International, Den Haag, 1996., str. 4.-5.

6 Vidi Ugovor o osnivanju Europske ekonomske zajednice (UEEZ) i, primjerice, Crnić-Grotić, V., Sgardelli Car, N., Ljudska prava u Europskoj uniji u praksi Europskog suda u Luxembourgu, Zbornik Pravnog fakulteta u Zagrebu, god. 60, br. 5, 2010., str. 971.; Von Bogdandy, A., The European Union as a Human Rights Organization? Human Rights and the Core of the European Union, Common Market Law Review, god. 37, br. 6, 2000., str. 1307.

7 Vidi, primjerice, Spojene Predmete 36/59 do 38/59 i 40/59 Präsident Ruhrkolen-Verkaufsgesellschaft mbH, Geitling RuhrkohlenVerkaufsgesellschaft mbH, Mausegatt Ruhrkohlen-Verkaufsgesellschaft mbH and I. Nold KG v High Authority of the European Coal and Steel Community [1960] ECR 00423. Ova presuda donesena je u kontekstu Europske zajednice za ugljen i čelik, kao preteče sadašnje integracije. Ovdje treba napomenuti i da je Sud u okviru integracije mijenjao nadležnosti i nazive, od Suda Europske zajednice za ugljen i čelik osnovanog 1952. do današnjeg Suda Europske unije. Vidi Crnić Grotić; Sgardelli Car, op. cit. u bilj. 6, str. 975.

8 Vidi Predmet 6/64 Flaminio Costa v E.N.E.L. [1964] ECR 00585 i Selanec, G., Povelja temeljnih prava Europske unije, u: Rodin, S.; Ćapeta, T.; Goldner Lang, I., Reforma Europske unije: Lisabonski ugovor, Narodne novine, Zagreb, 2009., str. 183. 
“Osnivanjem na neodređeno vremensko razdoblje Zajednice koja ima vlastite institucije, osobnost, pravnu sposobnost, sposobnost međunarodnog zastupanja i, točnije, stvarne ovlasti koje proizlaze iz ograničenja nadležnosti ili prijenosa ovlasti s država na Zajednicu, države članice su, premda u ograničenim područjima, ograničile svoja suverena prava i tako stvorile pravni sustav koji se primjenjuje kako na njihove državljane tako i na njih same.

Ugrađivanje odredaba koje potječu iz Zajednice u pravo svake države članice i općenito tekst i duh Ugovora posljedično uskraćuju državama članicama mogućnost da pred pravnim poretkom koji su prihvatile na temelju reciprociteta daju prednost naknadnoj jednostranoj mjeri. Takva mjera stoga ne može biti protivna tom pravnom sustavu.

Izvršna snaga prava Zajednice ne može se razlikovati od jedne države do druge zbog pridržavanja naknadnog nacionalnog zakonodavstva, a da to ne ugrozi ostvarenje ciljeva Ugovora iz članka 5. stavka 2. i dovede do diskriminacije zabranjene člankom 7."9

Ovakvom odlukom Sud je izdignuo pravnu snagu pravila EU-a iznad nacionalnih pravnih propisa. Navedeno tumačenje Sud je, u predmetu Simmenthal, poslije proširio i na ustave država članica koji sadrže odredbe o temeljnim materijalnim i postupovnim pravima. $\mathrm{Na}$ taj način pravo EU-a postavlja se iznad temeljnih načela pravnih sustava država članica, uključujući postupovna jamstva poput zabrane retroaktivnosti (ili zaštite legitimnih očekivanja). U konkretnom predmetu, riječ je bila o sukobu između prava tadašnje Europske ekonomske zajednice i poslije donesenog talijanskog zakona. Prema talijanskom Ustavu o neustavnosti zakona trebao je odlučiti talijanski Ustavni sud, no Sud je utvrdio da svaki nacionalni sud koji, u okviru svoje nadležnosti, mora primijeniti odredbe europskog prava, mora osigurati učinak tih pravnih pravila ostavljajući neprimijenjenom, ako je to potrebno, svaku suprotnu odredbu nacionalnog prava, bez potrebe da zatraži ili čeka prethodno stavljanje izvan snage takve nacionalne odredbe kroz bilo koji drugi postupak predviđen ustavom. ${ }^{10} \mathrm{Na}$ ovaj način se, u slučaju sukoba s europskim pravom, derogiraju ustavne odredbe o nadležnosti i postupku pred nacionalnim ustavnim sudovima, kao konzekvenca prethodno uspostavljenog načela nadređenosti prava EU-a.

Bilo je logično da će, na temelju opisanih tumačenja, Sud Europske unije uskoro rješavati situacije u kojima do izražaja dolaze temeljna ustavna načela država članica. To su, prvenstveno, situacije koje se tiču ljudskih prava, a za čiju primjenu tadašnji osnivački ugovori nisu sadržavali pravni temelj. Budući da se, prema prethodnoj praksi, u takvim slučajevima ne može primijeniti nacionalno ustavno pravo, bilo je potrebno u europskom pravu pronaći pravnu osnovu za primjenu temeljnih prava u pojedinim predmetima. Sud je, na tragu toga, u predmetu Stauder prvi put naveo da su temeljna ljudska prava ugrađena u temeljna načela prava Zajednice i uživaju sudsku zaštitu. ${ }^{11}$

Ostalo je pitanje izvora temeljnih načela europskog prava. U predmetu Internationale Handelsgesellchaft Sud je utvrdio da inspiracija za njihovu primjenu dolazi iz ustavnih tradicija

9 Vidi Costa v E.N.E.L., op. cit. u bilj. 8.

10 Vidi Predmet 106/77 Amministrazione delle Finanze dello Stato v Simmenthal SpA [1978] ECR 00629 točka 24.

11 Vidi Predmet 29/69 Erich Stauder v City of Ulm - Sozialamt [1969] ECR 00419 točka 7. Vidi, za analizu presude, primjerice, Pescatore, P., The Context and Significance of Fundamental Rights in the Law of the European Communities, Human Rights Journal, god. 2, br. 6, 1981., str. 295.-308. 
zajedničkim državama članica. ${ }^{12} \mathrm{U}$ predmetu Nold, izvor inspiracije je proširen na međunarodne sporazume za zaštitu ljudskih prava koje su potpisale države članice, poput Konvencije za zaštitu ljudskih prava i temeljnih sloboda. ${ }^{13}$ Važno je napomenuti da je praksa Suda ostavila širok prostor za definiranje i dodavanje novih općih načela prava u pravni poredak europske integracije. Pri tome je važno naglasiti da je obvezu poštovanja općih načela Sud proširio s europskih institucija i na tijela država članica u slučajevima u kojima primjenjuju europsko pravo. ${ }^{14} \mathrm{~S}$ druge strane, važno je naglasiti da, osim obveze njihova poštovanja, države članice mogu koristiti opća načela prava i za opravdanje vlastitih odstupanja od tržišnih pravila EU-a. U takvim situacijama nacionalna ograničenja moraju biti u skladu s načelom proporcionalnosti, gdje se obično ispituje može li se navedeni cilj postići drugim sredstvima koja su manje ograničavajuća za tržišne slobode od nacionalne mjere koja je u pitanju. ${ }^{15}$

Osnivanje Europske unije i njezino širenje nadležnosti u područja mnogo šira od zajedničkog (unutarnjeg) tržišta dovelo je do donošenja Povelje o temeljnim pravima EU-a i uključivanja temeljnih prava u Ugovor o Europskoj uniji. Tako je odredbama čl. 6. Ugovora o Europskoj uniji propisano da Unija priznaje prava, slobode i načela koja su određena Poveljom o temeljnim pravima Unije, koja ima istu pravnu snagu kao i osnivački ugovori. Propisano je i da se odredbama Povelje ne proširuju nadležnosti EU-a kako su određene Ugovorima. Dalje je propisano da EU pristupa Konvenciji za zaštitu ljudskih prava i temeljnih sloboda što se, zasad, nije dogodilo. Određeno je i da temeljna prava, kako su zajamčena Konvencijom za zaštitu ljudskih prava i temeljnih sloboda i kako proizlaze iz ustavnih tradicija zajedničkih državama članicama EU-a, predstavljaju opća načela prava Unije. ${ }^{16}$ Iz ovoga možemo zaključiti da trenutačno postoje tri izvora temeljnih prava u Uniji: ustavne tradicije zajedničke državama članicama, međunarodni ugovori koje su one sklopile te Povelja koja je pravno izjednačena s osnivačkim ugovorima.

Gdje je tu načelo zaštite legitimnih očekivanja? U praksi Suda ono je spomenuto i prije razvijanja koncepta općih načela prava, ${ }^{17}$ međutim svoje puno ozbiljenje doživjelo je upravo kroz primjenu općih načela od strane Suda. Povelja o temeljnim pravima EU-a sadrži određene odredbe kojima se štite prava stranaka vezana uz upravni postupak. Člankom 41. Povelje propisano je pravo na dobru upravu, na sljedeći način:

"1. Svatko ima pravo da institucije, tijela, uredi i agencije Unije njegove predmete obrađuju nepristrano, pravično i u razumnom roku.

2. To pravo uključuje:

12 Vidi Predmet 11/70 Internationale Handelsgesellschaft mbH $v$ Einfuhr- und Vorratsstelle für Getreide und Futtermittel [1970] ECR 01125 točka 4.

13 Vidi Predmet 4/73 J. Nold, Kohlen- und Baustoffgroßhandlung $v$ Commission of the European Communities [1974] ECR 00491 točka 13.

14 Vidi Predmet C-260/89 Elliniki Radiophonia Tiléorassi AE and Panellinia Omospondia Syllogon Prossopikou v Dimotiki Etairia Pliroforissis and Sotirios Kouvelas and Nicolaos Avdellas and others [1991] ECR I-02925 točka 43.

15 Vidi, primjerice, Predmet C-112/00 Eugen Schmidberger, Internationale Transporte und Planzüge v Republik Österreich [2003] ECR I-05659 točke 71-94. O načelu proporcionalnosti vidi, primjerice, i Harbo, T.-I., The Function of the Proportionality Principle in EU Law, European Law Journal, god. 16, br. 2, 2010., str. 158.-185.

16 Vidi Pročišćene verzije Ugovora o Europskoj uniji i Ugovora o funkcioniranju Europske unije [2016] Službeni list broj C202/1. Na temu pristupanja EU-ovoj Konvenciji i problemima koji mogu nastati, vidi Lock, T., EU Accession to the ECHR: Implications for Judicial Review in Strasbourg, European Law Review, god. 35, br. 1, 2010., str. 777.-798. 
(a) pravo svake osobe na saslušanje prije poduzimanja bilo kakve pojedinačne mjere koja bi na nju mogla nepovoljno utjecati;

(b) pravo svake osobe na pristup svojem spisu, uz poštovanje zakonitih interesa povjerljivosti te profesionalne i poslovne tajne;

(c) obvezu uprave da obrazloži svoje odluke.

3. Svaka osoba ima pravo da joj Unija naknadi svaku štetu koju njezine institucije ili službenici prouzroče pri obavljanju svojih dužnosti, u skladu s općim načelima koja su zajednička pravima država članica.

4. Svaka se osoba može pisanim putem obratiti institucijama Unije na jednom od jezika Ugovor i mora dobiti odgovor na istom jeziku."

Također se može spomenuti i čl. 20. Povelje, koji jamči jednakost pred zakonom. ${ }^{18}$ Izričitih odredaba o zaštiti legitimnih očekivanja i povezanog načela zaštite stečenih prava (koje ulazi u sadržaj načela pravne sigurnosti), ${ }^{19}$ u Povelji nema. Konvencija za zaštitu ljudskih prava i temeljnih sloboda također ne sadrži izričitu odredbu o zaštiti legitimnih očekivanja, no ona je priznata od strane Europskog suda za ljudska prava u smislu da se legitimna očekivanja stranaka pod određenim pretpostavkama moraju smatrati imovinom pod zaštitom članka 1. Protokola br. 1. Konvencije. ${ }^{20}$

Što se tiče ustavnih tradicija zajedničkih državama članica, situacija je kompliciranija. Ovdje se postavlja pitanje kako postupiti kada je određeno načelo prisutno u ustavnim tradicijama nekih država članica, a nekih ne. To je posebno bitno u kontekstu načela zaštite legitimnih očekivanja, budući da se radi o načelu koje je, kao što je spomenuto, proizašlo iz njemačkog pravnog sustava te se proširilo i na druge države članice te se njegov sadržaj u različitim jurisdikcijama može tumačiti na različite načine. ${ }^{21}$

Prema Sudu Europske unije, u slučajevima u kojima se zaštita općih načela prava koristi kao opravdanje za ograničenje tržišnih sloboda, nacionalna ograničavajuća mjera ne mora odgovarati konceptu koji sve države tumače na identičan način. ${ }^{22}$ Ovakav stav je prihvaćen i u pravnoj literaturi. ${ }^{23}$ Naravno, ovdje se postavlja pitanje o kojem broju država članica treba biti riječ. Je li dovoljno da većina njih poznaje određeni pravni institut da bi se on smatrao općim načelom prava? Što je sa situacijama u kojima neki pravni instituti imaju isti ili sličan naziv,

18 Vidi Povelju Europske unije o temeljnim pravima [2016] Službeni list, broj C202/389.

19 U literaturi vezanoj uz europsko upravno pravo zaštita legitimnih očekivanja i stečenih prava u pravilu se analiziraju zajedno. Vidi Šikić, Ofak, op. cit. u bilj. 4, str. 138. i, primjerice, Schønberg, S., Legitimate Expectations in Administrative Law, Oxford University Press, Oxford, 2000. Prema Đerđi, stečena prava su određena ovlaštenja koja je stranka stekla u prošlosti, dok su legitimna očekivanja usmjerena na pravo stranke da u budućnosti stekne određeno pravo koje joj zakon jamči u trenutku pokretanja upravnog postupka. Vidi Đerđa, op. cit. u bilj. 1, str. 96.

Predmet Pine Valley Developments LTD and Others v Ireland (zahtjev br. 12742/87) točka 51. O zaštiti legitimnih očekivanja vidi i u Omejec, J., Konvencija za zaštitu ljudskih prava i temeljnih sloboda u praksi Europskog suda za ljudska prava : strasbourški acquis, Novi informator, Zagreb, 2013.

22 Vidi Predmet C-36/02 Omega Spielhallen- und Automatenaufstellungs-GmbH v Oberbürgermeisterin der Bundesstadt Bonn [2004] ECR I-09609 točka 37.

23 Vidi, primjerice, Lenaerts, K., Gutman, K., "Federal Common Law" in the European Union: A Comparative Perspective from the United States, The American Journal of Comparative Law, god. 54, br. 1, 2006., str. 17. 
a različita značenja u raznim jurisdikcijama? Kako postupiti u situaciji u kojoj neki pravni institut u jednoj državi ima ustavnu težinu, poput zaštite legitimnih očekivanja u Njemačkoj ili u Hrvatskoj, ${ }^{24}$ dok u drugoj nema (poput Ujedinjene Kraljevine Velike Britanije i Sjeverne Irske) $?^{25}$

Na kraju ovog dijela može se zaključiti da je sustav pravnih izvora zaštite legitimnih očekivanja vrlo složen i slojevit. Nedostatak izričito propisanih odredaba ustavnog ranga na europskoj razini te različitost tradicija u državama članicama, dovode do nedostatka jasnoće pa i manjka pravne sigurnosti (koja je, paradoksalno, upravo povezana s načelom zaštite legitimnih očekivanja) u slučajevima primjene prava EU-a. U takvoj situaciji, Sud Europske unije ima ključnu ulogu u razvijanju načela zaštite legitimnih očekivanja u europskom pravu. Ovo je važno i za autonomiju država članica u području upravnog prava. Zaštita legitimnih očekivanja predstavlja opće načelo prava koje u EU-u ima pravnu snagu iznad razine sekundarnog zakonodavstva (što će biti prikazano u nastavku). Budući da opća načela prava obično ulaze u prostor temeljnih vrednota ustava država članica, Sud Europske unije postaje vrhovni arbitar odnosa između EU-a i ustavnih poredaka njezinih dijelova.

\section{NAČELO ZAŠTITE LEGITIMNIH OČEKIVANJA U PRAVU EUROPSKE UNIJE}

Ključnu ulogu u definiranju i primjeni načela zaštite legitimnih očekivanja u pravu EU-a dali su europski sudovi. S obzirom na nedostatak kodifikacije pravila vezanih uz ovo načelo, potrebno je analizirati navedenu sudsku praksu. Također, zbog česte manjkavosti obrazloženja, potrebno je u određenim situacijama i obraditi okolnosti samih slučajeva iz kojih se mogu pokušati izvući određeni zaključci o primjenjivosti argumentacije na slične predmete.

Prema praksi sudova EU-a, tri kumulativna uvjeta moraju biti zadovoljena da bi se stranka u postupku mogla pozvati na zaštitu legitimnih očekivanja, kako slijedi:

“Kao prvo, uprava mora osobi u pitanju pružiti precizna, bezuvjetna i podudarajuća jamstva koja potječu od ovlaštenog i pouzdanog izvora. Kao drugo, ta osiguranja moraju biti takva da se njima stvaraju osnovana (legitimna) očekivanja kod subjekta na koji se ona odnose. Kao treće, dana jamstva moraju biti u skladu s primjenjivim pravilima." ${ }^{26}$

Precizna, bezuvjetna i podudarajuća jamstva mogu proizlaziti iz različitih izvora. Prvo, može biti riječi o sekundarnom zakonodavstvu Unije, odnosno općim aktima poput uredbi i direktiva. U tom kontekstu posebno treba spomenuti područje Zajedničke poljoprivredne politike, gdje EU tradicionalno intervenira u tržišne uvjete vlastitim propisima, mijenjajući uvjete nekad u korist, a nekad na štetu poljoprivrednika. Slična je situacija u području kvota za uvoz proizvoda država nečlanica EU-a. Ovdje je važno naglasiti da sama promjena općih

\footnotetext{
24 Vidi U-IIIB-4366/2005 od 5. travnja 2006. točka 9. i Šikić, Ofak, op. cit. u bilj. 4, str. 137.

25 Vidi Thomas, R., The Protection of Legitimate Expectations in UK Administrative Law, The Protection of Legitimate Expectations under Administrative Law, Bergen, 2012., str. 8.

26 Vidi Spojene Predmete T-60/06 RENV II i T-62/06 RENV II Italian Republic v European Commission ECLI:EU:T:2016:233 točka 178.
} 
propisa ne stvara legitimna očekivanja u situacijama u kojima tijela Unije imaju diskrecijsko pravo donijeti određene odluke. Navedena diskrecija proizlazi iz samih Ugovora, koji zakonodavcu EU-a (Vijeće, odnosno Parlament) daju pravo da, prema propisanoj proceduri, donose zakonodavne akte radi ostvarivanja ciljeva predviđenih Ugovorima. ${ }^{27}$

Pojedine odredbe zakonodavnih akata Unije ipak se mogu proglasiti nevaljanim zbog povrede načela legitimnih očekivanja. Najpoznatiji primjer u tom smislu predstavlja odluka u predmetu Mulder. Riječ je bila o situaciji u kojoj je Uredbom Vijeća 1078/77 određena premija za poljoprivrednike koji prestanu proizvoditi mlijeko, zbog viškova na tržištu. Stranka u postupku, nakon isteka pet godina neproizvodnje, nije bila u mogućnosti obnoviti proizvodnju, budući da je osporena Uredba 857/84 propisivala da pravo na proizvodnu kvotu mogu ostvariti samo oni poljoprivrednici koji su proizvodili mlijeko u prethodnoj referentnoj godini u kojoj stranka nije proizvodila mlijeko. U ovom slučaju je bitno naglasiti da je stranka sklopila ugovor s nizozemskim vlastima nadležnim za provedbu Zajedničke poljoprivredne politike, koji je stvorio legitimno očekivanje zajedno s Uredbom 1078/77. ${ }^{28}$ Iz sudske je prakse ipak teško izvući općenit zaključak, odnosno kriterij, u kojim slučajevima je zakonodavac EU-a vezan legitimnim očekivanjima stranaka koje je stvorilo prethodno, u međuvremenu izmijenjeno, zakonodavstvo Unije, izvan specifičnih okolnosti pojedinog predmeta.

Kronološki, zaštita legitimnih očekivanja u praksi Suda EU-a prvo se razvila vezano uz upravne odluke tijela Unije. Naravno, da bi se stranka mogla pozvati na zaštitu legitimnih očekivanja, mora biti riječ o pravomoćnoj upravnoj odluci. ${ }^{29}$ Ovdje je problem u tome što Europska unija nema jedan kodificiran upravni postupak s definiranim redovnim i izvanrednim pravnim lijekovima te pravomoćnost može značiti različite stvari vezano uz različite odluke. Slika postaje još složenija kad se uzmu u obzir upravni akti država članica pri primjeni prava EU-a, poput pravila o državnim potporama, što će biti pobliže analizirano u sljedećem poglavlju.

Što se tiče upravne prakse, jurisprudencija europskih sudova čini se kontradiktornom, ili u najmanju ruku nedovoljno dosljednom. Sud je tako, primjerice, u kontekstu kvota za proizvodnju čelika Europske zajednice za ugljen i čelik (predmet Ferriere San Carlo), zaključio da je tolerancija Europske komisije na prebačaj proizvodnih kvota stvorila legitimna očekivanja proizvođača da će se navedena praksa nastaviti i u budućnosti. ${ }^{30} \mathrm{~S}$ druge strane, Sud je utvrdio da određena praksa izračunavanja kazni za prekršitelje u području tržišnog natjecanja ne stvara obvezu za Komisiju da se navedene prakse pridržava u budućnosti. Sud je pri tome izričito naveo da njegov vlastiti prethodni stav iz odluke Ferriere San Carlo nije primjenjiv u području tržišnog natjecanja u kojemu Komisija ima široku diskreciju odlučivanja o sankcijama za prekršitelje. ${ }^{31}$ Sud pri tome nije objasnio koja je razlika između zaštite tržišnog natjecanja

27 Vidi Predmet C-284/94 Kingdom of Spain v Council of the European Union [1998] ECR I-07309 točka 43.

28 Vidi Predmet 120/86 J. Mulder v Minister van Landbouw en Visserij [1988] ECR 02321. Smjernice Komisije koje su, u kontekstu pojedinih politika EU-a, obvezujuće za države članice i stvaraju učinke slične zakonodavnim aktima, također mogu stvoriti legitimna očekivanja. Vidi, primjerice, Predmet C-313/90 Comité International de la Rayonne et des Fibres Synthétiques and others $v$ Commission of the European Communities [1993] ECR I-01125 točke 34.-36. i Craig, de Burca, op. cit. u bilj. 4, str. 561. 
i kvota za čelik, budući da su ovlasti Komisije u obje situacije vrlo slične. Ako je sud smatrao da postoji bitna razlika između ova dva područja djelatnosti EU-a, svakako je trebao objasniti koje su to razlike, odnosno po čemu je kontekst zaštite tržišnog natjecanja specifičan. Iz doslovnog čitanja presude proizlazi da su ovlasti Komisije u području tržišnog natjecanja veće od njezinih ovlasti u drugim područjima djelovanja, što nikako nije dobro za pravnu sigurnost i graniči s arbitrarnosti. Problem je u tome što su ovlasti Komisije u pojedinim područjima definirane Ugovorima te bi Sud, u postavljanju distinkcija između različitih područja, trebao vlastitu argumentaciju temeljiti na sadržajnim razlikama koje proizlaze iz teksta ili svrhe Ugovora, a ne općenito utvrditi da ista načela ne vrijede ili imaju drukčije značenje u kontekstu jedne od Unijinih politika. Komisija svakako ima široku slobodu odlučivanja o sankcijama za prekršitelje pravila o zaštiti tržišnog natjecanja, no ona je praktično široku autonomiju imala i u području kvota za čelik te distinkcija između ovih područja nije najjasnija.

Naposljetku, legitimna očekivanja mogu proizlaziti i iz drugih akata upravnih tijela Unije, odnosno Komisije, poput obavijesti o primjeni pokajničkog programa u području tržišnog natjecanja, prema praksi Suda. Ovdje je važno naglasiti da je riječ o obavijestima o slučajevima oslobođenja ili smanjenja kazni danima od strane tijela nadležnog za izricanje sankcija u jasno određenom obliku objavljenim u Službenom listu EU-a. Također je važno naglasiti da su obavijesti kojima se bavio Sud, vezane uz pokajničke programe, sadržavale izričitu izjavu da je Komisija svjesna da će one stvoriti legitimna očekivanja, na koja se mogu osloniti poduzetnici kada otkrivaju povrede prava tržišnog natjecanja Komisiji. ${ }^{32} \mathrm{U}$ takvim situacijama, opisani akti stvaraju legitimna očekivanja stranaka.

Nakon analize pravnih osnova iz kojih mogu proizaći legitimna očekivanja, potrebno se osvrnuti na sam pojam legitimnosti. S obzirom na kazuističku prirodu prava EU-a u ovom području, najbolje je prikazati situacije u kojima je Sud utvrdio da očekivanja nisu legitimna. Ovdje je važno naglasiti da se očekivanja koja nisu razumna, odnosno postojana, ne mogu smatrati legitimnim. Drugim riječima, ako se promjene mogu predvidjeti, kao što je čest slučaj u području Zajedničke poljoprivredne politike, ne može se govoriti o legitimnim očekivanjima. ${ }^{33}$ Također, neće biti riječi o legitimnim očekivanjima kad su posrijedi odluke kojima se zatvaraju pravne praznine koje omogućavaju trgovcima ostvarivanje spekulativne dobiti na tržištu hrane. ${ }^{34}$ Vezano uz ovo tumačenje, javljaju se određene nejasnoće. Tržišno gospodarstvo se temelji na planiranju budućih poslovnih poteza radi ostvarivanja dobiti i u tom slučaju se nužno uzimaju u obzir promjene u regulatornom okruženju. Drugim riječima, svaka promjena propisa, pogotovo u izrazito reguliranim sektorima poput proizvodnje hrane, može se iskoristiti za poboljšavanje vlastite poslovne pozicije te je vrlo teško definirati kada takva praksa predstavlja spekulaciju prema Sudu EU-a.

Posljednji uvjet koji određuje pravo EU-a za primjenu načela legitimnih očekivanja jest zakonitost. Ovdje je potrebno naglasiti važnost načela zakonitosti kao najviše pravne vrijed-

af 1998 (Deutschland) GmbH (C-208/02 P) and ABB Asea Brown Boveri Ltd (C-213/02 P) v Commission of the European Communities [2005] ECR I-05425 točke 172.-175., 196.

Vidi Predmet C-517/15 P AGC Glass Europe and Others v European Commission ECLI:EU:C:2017:598 točka 77. i Obavijest Komisije o oslobađanju od kazni i smanjenju kazni u slučajevima kartela [2006] Službeni list, broj C298/17.

Vidi Predmet 265/85 Van den Bergh en Jurgens BV and Van Dijk Food Products (Lopik) BVv Commission of the European Communities [1987] ECR 01155 točka 45. 
nosti, u odnosu na koju zaštita legitimnih očekivanja predstavlja određeno odstupanje. Iz navedenog razloga, jamstva koja su dana moraju biti u skladu s primjenjivim pravilima. ${ }^{35}$ To je logično i zato što se razumna osoba ne bi oslonila na nezakonitu osnovu stjecanja ili daljnjega korištenja nekog prava. Zbog tog razloga, u teoriji se navodi da legitimno očekivanje mora biti utemeljeno na pravnoj normi, bez obzira na oblik i hijerarhijsku snagu njezina izvora, tako da se pitanje zakonitosti u zaštiti legitimnih očekivanja ne smije dovesti u pitanje. Koliko god razumno očekivanje bilo svrhovito za pojedinca, ono se neće štititi ako je suprotno pravu. ${ }^{36}$ Ipak i ovdje, kao što je čest slučaj u europskom pravu, postoje iznimke i nedosljednosti. Prema Sudu, iako svakoj instituciji EU-a koja utvrdi da akt koji je upravo usvojila sadrži nezakonitost treba priznati pravo da taj akt povuče u razumnom roku s retroaktivnim učinkom, to pravo može biti ograničeno potrebom poštovanja legitimnih očekivanja stranke koja se mogla pouzdati u njegovu zakonitost. ${ }^{37}$ Tako protupravna upravna odluka (Komisije) koja nije stavljena izvan snage u razumnom roku može stvoriti legitimna očekivanja kod stranaka u postupku, kao što je utvrdio Sud u predmetu Consorzio Cooperative d'Abruzzo v Commission. ${ }^{38}$ U konkretnom slučaju riječ je bila o području Zajedničke poljoprivredne politike gdje je Komisija napravila pogrešku pri izračunu novčanog doprinosa zbog čega je odluka iz 1982. bila protupravna te je stavljena izvan snage novom odlukom iz 1984. Sud je utvrdio da rok od više od dvije godine između donošenja odluka nije bio razuman, budući da je Komisija i ranije mogla utvrditi nezakonitost prve odluke. ${ }^{39}$ Iz ovakve odluke ipak je teško izvući neko generalno pravilo ili smjernicu za buduće slučajeve. Teško je utvrditi u kojem trenutku je netko u upravnom tijelu (Komisiji) znao ili mogao zaključiti da je neka njegova odluka protupravna. U situaciji u kojoj nema jasno propisanih rokova, do izražaja dolazi kazuistička jurisprudencija Suda, koja zbog nedostatka općih kriterija ne doprinosi pravnoj sigurnosti.

Suprotna je situacija s drugim postupanjima uprave. Sud je tako, u predmetu Thyssen AG $v$ Commission of the European Communities, utvrdio da obećanja koja su dana stranci od strane službenika upravnog tijela (Komisije) ne mogu dovesti do legitimnih očekivanja ako su dana contra legem. ${ }^{40}$ Sud pri tome nije objasnio zašto druga (protupravna) postupanja uprave ne mogu stvoriti legitimna očekivanja, dok je to moguće u slučaju upravnih odluka. Pri donošenju zaključka važno je napomenuti da je bila riječ o obećanju koje nije dano u propisanom obliku niti je bilo posrijedi jamstvo stjecanja prava koje bi na bilo koji način imalo pravnu snagu upravnog akta, kao što je to u hrvatskom upravnom pravu. ${ }^{41}$ Ipak, bilo bi dobro da je Sud pružio dodatnu argumentaciju, kako bi razjasnio može li ikada protupravno drugo postupanje uprave dovesti do legitimnih očekivanja. Prema postojećoj praksi čini se da ne može.

35 Vidi Italian Republic v European Commission, op. cit. u bilj. 26, točka 178. i Đerđa, op. cit. u bilj. 1, str. 88.

36 Vidi Italian Republic v European Commission, op. cit. u bilj. 26, točka 178. Vidi Đerđa, op. cit. u bilj. 1, str. 91.

37 Vidi Predmet T-233/16 P José Luis Ruiz Molina v European Union Intellectual Property Office ECLI:EU:T:2017:435 točka 27. Vidi za prethodne slučajeve i, primjerice, Predmet 54/77 Antoon Herpels v Commission of the European Communities [1978] ECR 00585 točka 38.

Vidi Predmet 15/85 Consorzio Cooperative d'Abruzzo v Commission of the European Communities [1987] ECR 01005 točke 14.-17.

Vidi Consorzio Cooperative d'Abruzzo v Commission of the European Communities, op. cit. u bilj. 38, točka 16.

Vidi Predmet 188/82 Thyssen AG v Commission of the European Communities [1983] ECR 03721 točka 11. Vidi također i Predmet T-2/93 Société Anonyme à Participation Ouvrière Compagnie Nationale Air France v Commission of the European Communities [1994] ECR II-00323 točke 101.-102.

Vidi čl. 103. Zakona o općem upravnom postupku, Narodne novine, broj 47/2009 i Đerđa, op. cit. u bilj. 1, str. 108. 
Na kraju ovog dijela treba spomenuti da, čak i u slučaju u kojem postoje legitimna očekivanja, ona se ne moraju zaštititi ako postoji suprotni javni interes koji je jači od potrebe zaštite legitimnih očekivanja. ${ }^{42} \mathrm{U}$ praksi će teško biti utvrditi o kakvim je interesima riječ. Čini se da je Sud sklon analizi kojom ispituje može li se navedeni cilj zaštite javnog interesa postići drugim sredstvima koja su manje ograničavajuća za legitimna očekivanja stranaka, što predstavlja oblik testa proporcionalnosti. ${ }^{43}$

Analiza sudske prakse ukazala je na više otvorenih pitanja. Ta pitanja uključuju, među ostalim, kada je zakonodavac EU-a vezan legitimnim očekivanjima stranaka koje je stvorilo prethodno, u međuvremenu izmijenjeno, zakonodavstvo Unije; u kojim situacijama prethodna upravna praksa stvara legitimna očekivanja; nelegitimnost očekivanja koja su nastala u spekulativne svrhe; razliku u pravnoj snazi protupravnih upravnih odluka i drugih postupanja uprave za nastanak legitimnih očekivanja. Navedena otvorena pitanja prvenstveno su proizvod (naizgled) nedosljednosti u sudskoj praksi kao i nedostatku dovoljnog obrazloženja pojedinih odluka. To posebno dolazi do izražaja u situaciji u kojoj su pravni izvori načela zaštite legitimnih očekivanja u nekodificiranom pravu temeljenom na kazuistici. Opisana situacija općenito nije povoljna za zaštitu pravne sigurnosti, kao načela koje je izuzetno povezano upravo sa zaštitom legitimnih očekivanja.

\section{PRAVNA AUTONOMIJA DRŽAVA ČLANICA}

Postupovni propisi država članica EU-a nisu generalno ujednačeni na razini Unije. To ipak ne znači da je nacionalna autonomija u ovom području neograničena, budući da pravni sustav EU-a postavlja ograničenja koja države moraju poštovati. Tako čl. 19. Ugovora o Europskoj uniji sadrži odredbu prema kojoj države članice moraju osigurati pravne lijekove koji su dostatni za osiguranje učinkovite pravne zaštite u područjima koja su obuhvaćena pravom EU-a. Spomenuta odredba predstavlja izraz načela djelotvorne pravne zaštite kao općeg načela prava Unije. ${ }^{44}$ Pravo na djelotvoran pravni lijek zaštićeno je i čl. 47. Povelje o temeljnim pravima Unije, unutar područja primjene prava EU-a. Važnost ovog načela sastoji se u tome što postupovna pravila država članica moraju zadovoljiti dva osnovna uvjeta. Prvo, sukladno načelu ekvivalentnosti, postupovna pravila za pravna sredstva namijenjena zaštiti prava koja pojedinci izvode iz prava EU-a ne smiju biti nepovoljnija od onih koja se odnose na slična pravna sredstva u internom pravu država članica. Drugo, sukladno načelu djelotvornosti, postupovna pravila za pravna sredstva namijenjena zaštiti prava koja pojedinci izvode iz prava EU-a ne smiju biti uređena na način da učine pretjerano otežanim ili praktično nemogućim izvršavanje prava dodijeljenih pravnim poretkom EU-a. ${ }^{45}$

42 Vidi Predmet 74/74 Comptoir national technique agricole (CNTA) SA v Commission of the European Communities [1975] ECR 00533 točka 43.

Vidi Predmet C-183/95 Affish BVv Rijksdienst voor de keuring van Vee en Vlees [1997] ECR I-04315 točke 57.-59.

Vidi Predmet C-432/05 Unibet (London) Ltd, Unibet (International) Ltd v Justitiekanslern [2007] ECR I-02271 točka 37. Vidi na ovu temu također Arnull, A., The Principle of Effective Judicial Protection in EU law: an Unruly Horse?, European Law Review, god. 36, br. 1, 2011., str. 68. 
Opisana načela predstavljaju okvir primjene nacionalnih postupovnih pravila u slučajevima primjene prava EU-a. Na taj način, u ovakvim situacijama ograničena je postupovna autonomija država članica. Navedena ograničenja odnose se i na praktičnu primjenu načela zaštite legitimnih očekivanja u situacijama u kojima države članice primjenjuju pravo EU-a. Pri tome treba naglasiti da pravna doktrina razlikuje postupovnu i materijalnu vrstu zaštite legitimnih očekivanja. Postupovna zaštita osigurava stranci čija su legitimna očekivanja povrijeđena određena postupovna prava prije donošenja nove odluke, poput pružanja mogućnosti izjašnjavanja u postupku i slično. Materijalna (supstantivna) zaštita daje stranci mogućnost ostvariti zahtjev za novom meritornom odlukom koju je legitimno mogla očekivati pred upravnim tijelom. Ona se ovlaštenicima stečenih prava osigurava kroz institut pravomoćnosti te zabranom intervencije u pravomoćnu upravnu odluku osim u zakonom propisanim slučajevima. ${ }^{46} \mathrm{U}$ kontekstu postupovne autonomije država članica, obuhvaćene su obje navedene vrste zaštite legitimnih očekivanja.

Pri analizi autonomije država članica vezano uz zaštitu legitimnih očekivanja stranaka posebno je važno načelo djelotvornosti. Ono je važno zbog toga što, u praksi, upravna tijela država članica (kada primjenjuju pravo EU-a) dovodi u neravnopravan položaj u odnosu na tijela same Europske unije. To se prvenstveno odnosi na poštovanje načela zakonitosti. Kao što je navedeno u prethodnom poglavlju, nezakonite upravne odluke Komisije mogu stvoriti legitimna očekivanja u određenim situacijama. S druge strane, prema praksi Suda EU-a, država članica EU-a čija su upravna tijela dodijelila državnu potporu protivno pravilima postupka koje propisuje pravo EUa, ne može se pozivati na zaštitu legitimnih očekivanja korisnika kako bi izbjegla svoju obvezu da poduzme potrebne mjere za izvršenje odluke Komisije u kojoj joj se nalaže da navedenu potporu povrati ili to može učiniti iznimno rijetko. Prema Sudu, dopustiti takvu mogućnost lišilo bi odredbe Ugovora o državnim potporama njihovih korisnih učinaka, budući da bi se tijela država članica tako mogla pozivati na vlastito nezakonito ponašanje kako bi onemogućila djelotvornost odluka koje Komisija donosi na temelju navedenih odredaba Ugovora. ${ }^{47}$

Logika Suda ima smisla u kontekstu osiguranja primjene prava EU-a od strane država članica, no problematična je iz perspektive pravne sigurnosti i koherentnosti pravnog sustava EU-a. Budući da primjena prava EU-a u praksi ovisi o upravnim tijelima država članica, ta tijela sa svojim upravnim odlukama predstavljaju dio pravnog sustava Unije. Davanje nezakonitim upravnim odlukama nekih tijela koja primjenjuju europsko pravo mogućnosti stvaranja legitimnih očekivanja, uz uskraćivanje iste mogućnosti upravnim odlukama drugih tijela koja primjenjuju europsko pravo, nije dobro za pravnu sigurnost te ruši dosljednost i ujednačenost pravnog sustava Unije. Situacija postaje još kompleksnija kada se uzme u obzir predmet Salzgitter. U njemu je Opći sud utvrdio da nepoštovanje postupovnih pravila EU-a o državnim potporama (neispunjenje obveze prethodnog obavještavanja Komisije) onemogućuje pozivanje na legitimna očekivanja korisnika potpore, osim u iznimnim okolnostima, bez preciziranja

and Comparative Law, god. 19, br. 3, 2012., str. 393. Navedena načela inkorporirana su u određene akte sekundarnog zakonodavstva Unije. Vidi, primjerice, 89/665/EEZ: Direktivu Vijeća od 21. prosinca 1989. o usklađivanju zakona i drugih propisa u odnosu na primjenu postupaka kontrole na sklapanje ugovora o javnoj nabavi robe i javnim radovima [1989] Službeni list, broj L395/33. Vidi, na temu postupovne autonomije država članica i, primjerice, Kakouris, H. C., Do the Member States Possess Judicial Procedural “Autonomy"?, Common Market Law Review, god. 34, br. 6, 1997., str. 1389.-1412. i Kilpatrick, C., The Future of Remedies in Europe, u: Kilpatrick, C.; Novitz, T.; Skidmore, P., The Future of Remedies in Europe, Hart Publishing, Oxford, 2000., str. 1. 
koje bi to okolnosti mogle biti. S druge strane, stranke se i u takvim slučajevima mogu pozvati na zaštitu načela pravne sigurnosti (u konkretnom slučaju zbog predugog vremena koje je Komisiji trebalo da donese odluku), budući da njegova primjena ne ovisi isključivo o uvjetima za primjenu načela zaštite legitimnih očekivanja. ${ }^{48}$ Ipak, mada se stranke na duljinu trajanja postupka Komisije nisu mogle pozvati u predmetu Salzgitter, to im je od strane Općeg suda bilo omogućeno u predmetu CETM. U potonjem predmetu je Opći sud na kraju utvrdio da duljinu trajanja nije bila tolika da dovede do povrede načela legitimnih očekivanja. ${ }^{49}$ Kasnija sudska praksa nije jasno razriješila opisane dileme vezane uz primjenu načela zaštite legitimnih očekivanja u slučajevima nezakonitih odluka tijela država članica. Ipak, čini se da je ta primjena praktički nemoguća. ${ }^{50}$ Iz svega ovoga vidi se da sustav s toliko iznimaka koje može ili ne mora prihvatiti Sud EU-a teško može zadovoljiti načelo pravne sigurnosti.

Osim navedenog, autonomija država članica u analiziranom području je ograničena u još jednom bitnom smislu. U slučaju isteka nacionalnog zakonskog roka za ukidanje nezakonitog rješenja (koji poznaje i hrvatsko upravno pravo), ${ }^{51}$ može doći do situacije da se pravo EU-a ne može primijeniti. Primjer za ovo je nezakonito dodijeljena državna potpora, koja prema pravilima EU-a mora biti vraćena. Međutim, dolazi do problema u slučaju u kojem je istekao zakonski rok države članice za ukidanje upravnog akta kojim je potpora dodijeljena. U takvim slučajevima, prema Sudu EU-a, država članica ne može se pozivati na nacionalna pravila upravnog postupka zbog povrede načela djelotvornosti prava EU-a. ${ }^{52}$ Pri tome nije jasno je li svaki rok koji propisuju nacionalni zakoni kojima se uređuje upravni postupak suprotan pravu EU-a ako je taj rok u konkretnom slučaju istekao ili to ovisi o njegovoj duljini. Prema praksi Suda EU-a u području državnih potpora čini se da je ispravna prva tvrdnja, budući da su mogućnosti nevraćanja nezakonito dodijeljenih državnih potpora svedene na minimum. Ipak, ovo je još jedno područje u kojem se vide sve manjkavosti pravnog okvira EU-a utemeljenog na nekodificiranim načelima i neujednačenim postupcima. Opisana situacija navodi na potrebu razmišljanja o mogućnostima određenog ujednačavanja i kodifikacije, što će biti analizirano u idućem poglavlju.

\section{KODIFIKACIJA KAO RJEŠENJE?}

Analiza ukazuje na više nedosljednosti i neriješenih pitanja vezanih uz načelo zaštite legitimnih očekivanja u europskom pravu. Ovo se odnosi kako na situacije u kojima isključivo tijela

48 Vidi Predmet T-308/00 Salzgitter AG v European Commission [2004] ECR II-01933 točke 165-166. Sud je ukinuo navedenu odluku Općeg suda utvrdivši da načelo pravne sigurnosti nije bilo povrijeđeno, ali je načelno dopustio mogućnost njegove primjene u situaciji u kojoj je odluka o dodjeljivanju potpore bila nezakonita. Vidi Predmet C-408/04 P Commission of the European Communities v Salzgitter AG [2008] ECR I-02767 točke 98.-108.

49 Vidi Predmet T-55/99 Confederación Española de Transporte de Mercancías (CETM) v Commission of the European Communities [2000] ECR II-03207 točka 137.

50 Vidi, primjerice, Spojene Predmete T-233/11 i T-262/11 Hellenic Republic and Ellinikos Chrysos AE Metalleion kai Viomichanias Chrysou v European Commission ECLI:EU:T:2015:948 točke 197.-199.

51 Vidi čl. 129. Zakona o općem upravnom postupku, op. cit. u bilj. 41.

52 Vidi Commission of the European Communities v Federal Republic of Germany, op. cit. u bilj. 47, točka 18. Paradoksalno, riječ je bila upravo o njemačkim propisima o upravnom postupku koji su predstavljali inspiraciju za uvođenje načela zaštite legitimnih očekivanja u pravni sustav EU-a. 
EU-a primjenjuju pravo Unije, tako na situacije u kojima to rade tijela država članica uz nadzor od strane tijela Unije (primjerice, u području državnih potpora). Ovdje je posebno važno pitanje zakonitosti, odnosno situacija u kojima i nezakonite upravne odluke mogu stvarati pravno zaštićena legitimna očekivanja. Nedosljednosti postoje kako u primjeni prava EU-a od strane Komisije (razlika u pravnoj snazi protupravnih upravnih odluka i drugih postupanja Komisije za nastanak legitimnih očekivanja), tako u primjeni prava EU-a od strane nacionalnih tijela koja su podvrgnuta strožoj kontroli u odnosu na tijela Unije. Navedene razlike proizlaze iz kazuističke prirode sudske prakse i nedostatka jasnih i ujednačenih propisa EU-a koji bi bili jednako primjenjivi u svim sektorima. Potonje se jasno vidi iz nejasnog određenja situacija u kojima prethodna upravna praksa stvara legitimna očekivanja, gdje se čini da je takva mogućnost znatno ograničenija u području tržišnog natjecanja, nego u drugim područjima prava Unije. Na ovaj način, pretežno sektorska priroda upravnog prava EU-a ${ }^{53}$ predstavlja zapreku za jasnije i koherentnije uređenje upravnog postupka pred tijelima Unije.

Dosad je bilo više inicijativa za kodifikacijom upravnog postupka pred tijelima Unije. Bez potrebe detaljnog analiziranja svih njih, ${ }^{54}$ u ovoj prigodi koncentrirat ćemo se na one najvažnije. Radi toga potrebno je spomenuti inicijativu pučkoga pravobranitelja EU-a, koji je nastojao razraditi pojam "dobre uprave" te utvrditi kako se navedeni pojam treba tumačiti u praksi. Zbog navedenog razloga izradio je Europski kodeks dobrog upravnog postupanja, koji određuje značajan broj pravila koja tijela Unije trebaju primjenjivati u odnosu na pojedince. Što se tiče načela zaštite legitimnih očekivanja, čl. 10. Kodeksa određuje da su službenici dužni poštovani legitimna i razumna očekivanja pojedinaca u odnosu na prethodno postupanje institucije (tijela) Unije. Člankom 4. Kodeksa određena je zaštita načela zakonitosti. Članak 17. Kodeksa određuje da se odluke trebaju donijeti bez odgode, a najkasnije u roku od dva mjeseca od podnošenja zahtjeva, osim ako to, zbog kompleksnosti predmeta, nije moguće. U potonjem slučaju odluku treba donijeti u najkraćem mogućem roku. ${ }^{55}$

Odredbe Kodeksa, mada korak u dobrom smjeru, ne rješavaju praktične probleme prikazane u prethodnim poglavljima, vezane uz načelo zaštite legitimnih očekivanja. One su dosta široko postavljene i neodređene te se u ovom dijelu uglavnom svode na isticanje načela koja su prihvaćena u praksi i čije samo postojanje nije dvojbeno. Nešto detaljnije odredbe sadrži Rezolucija Europskog parlamenta o otvorenoj, učinkovitoj i neovisnoj upravi Europske unije, čiji je sastavni dio Prijedlog Uredbe Europskog parlamenta i Vijeća za otvorenu, učinkovitu i neovisnu Europsku administraciju. One koje se tiču zaštite legitimnih očekivanja uglavnom su sadržane u Preambuli, kako slijedi:

"(37) Načelom zakonitosti kao izravnom posljedicom vladavine prava upravi Unije nameće se obveza da ispravi ili povuče nezakonite upravne akte. Međutim, s obzirom na to da se ispravljanjem ili povlačenjem upravnog akta može povrijediti zaštita legitimnih očekivanja i načela pravne sigurnosti, uprava Unije trebala bi pažljivo i nepristrano procijeniti učinak ispravljanja ili povlačenja akta na ostale stranke te priložiti zaključke te procjene obrazloženju o njegovu ispravljanju ili povlačenju.

53 Na ovu temu vidi Đerđa, D., Pravila upravnog postupka u europskom pravu, Zbornik Pravnog fakulteta Sveučilišta u Rijeci, god. 33 , br. 1, 2012., str. 109.-144. i Jerčinović, A., Novi trendovi u kodifikaciji pravila upravnog postupka u Europskoj uniji, Hrvatska pravna revija, br. 3, 2018., str. 79.-84. 
(...) 41) Načelo zaštite legitimnih očekivanja proizlazi iz vladavine prava i njime se podrazumijeva da se djelovanjem javnih tijela ne bi trebalo zadirati u neotuđiva prava i pravomoćne pravne situacije osim tamo gdje je to prijeko potrebno i u javnom interesu. Legitimna očekivanja trebala bi se uzeti u obzir u slučaju ispravljanja ili povlačenja upravnog akta." 56

Citirane odredbe stavljaju u kontrapoziciju načelo zakonitosti i načelo zaštite legitimnih očekivanja, no taj odnos jasno ne razrješavaju. Također se navodi da bi se legitimna očekivanja trebala uzeti u obzir u slučaju ispravljanja ili povlačenja upravnog akta. Budući da uzimanje u obzir nije jasan pravni standard i ovdje se ostavlja prostor za različita tumačenja od strane europskih sudova. Člankom 24. pak propisano je:

"Nadležno tijelo može ispraviti ili povući zakoniti upravni akt s povoljnim učinkom za stranku na vlastitu inicijativu ili na zahtjev druge stranke ako razlozi koji su doveli do donošenja određenog akta više ne postoje. Legitimna očekivanja ostalih stranaka uzimaju se u obzir."

Navedena odredba je bitna, budući da bi se ona mogla tumačiti na način da samo zakoniti upravni akti mogu stvoriti legitimna očekivanja, što znači da nema iznimaka kakve su dopuštali europski sudovi.

S druge strane, u ovom dijelu je svakako potrebno spomenuti i ReNEUAL istraživačku mrežu za upravno pravo EU-a. Ova mreža, koja okuplja stručnjake iz niza država članica EU-a, razvila je model pravila radi ujednačavanja i simplifikacije upravnog postupka pred tijelima Unije. ${ }^{57}$ Važno je naglasiti da Preambula model pravila određuje zaštitu legitimnih očekivanja kao načelo koje se uzima u obzir pri tumačenju model pravila. Uz navedeno, ključne su odredbe čl. III-36:

"(1) The public authority may rectify or withdraw an unlawful decision that is beneficial to a party. It may exercise this power ex-officio, or following a request by another party. This power may be exercised outside the time-limits for legal challenge.

(2) The public authority shall take into account the extent to which a party has a legitimate expectation that the decision was lawful and the extent to which a party has relied on it when deciding,

(a) whether to exercise the power in paragraph 1 ,

(b) whether, if the power to rectify or withdraw is exercised, it should have retroactive or prospective effect.

(3) The public authority may rectify or withdraw a lawful decision that is beneficial to a party. It may exercise this power ex-officio, or following a request by another party. This power may be exercised outside the time-limits for legal challenge in the following circumstances:

(a) where it is permitted by sector-specific law,

(b) where the party has not complied with an obligation specified in the decision, or has not done so within the time-limit set for compliance,

56 Vidi Rezoluciju Europskog parlamenta o otvorenoj, učinkovitoj i neovisnoj upravi Europske unije, (2016/2610(RSP)).

57 Vidi Research Network on EU Administrative Procedure, ReNEUAL Model Rules on EU Administrative Procedure, 2014. 
(c) in order to prevent or eliminate serious harm. The public authority shall upon application make good the disadvantage to the party affected deriving from reliance on the continued existence of the decision to the extent that this merits protection.

(4) The public authority when exercising the power in this Article shall take into account the effect of the rectification or withdrawal on other parties and on third parties.

(5) Rectification or withdrawal shall have retroactive effect only if it occurs within a reasonable time.

(6) Rectification or withdrawal pursuant to this Article constitutes an administrative procedure as defined in Article I-4(2)."

Citirane odredbe odražavaju u bitnim elementima praksu Suda EU-a, sa svim njezinim nedorečenostima. Posebno je dvojbeno ostavljanje mogućnosti da nezakonite upravne odluke stvaraju legitimna očekivanja, derogirajući na taj način prije svega načelo zakonitosti kao jedno od općih načela prava EU-a. Svakako bi buduća zakonodavna rješenja na razini Unije trebala jasno isključiti mogućnost da nezakoniti upravni akti stvaraju legitimna očekivanja, jer bi se na taj način izbjegle nejasnoće koje postoje pri primjeni prava EU-a od strane upravnih tijela Unije. Na taj način ne bi postojao ni različiti tretman nezakonitih nacionalnih upravnih odluka koje praktički ne mogu stvoriti legitimna očekivanja. Također bi trebalo izbjegavati nejasne i gotovo arbitrarne situacije, poput isključenja legitimnosti očekivanja koja su nastala u spekulativne svrhe, budući da nije jednostavno definirati kriterije kada je nešto spekulacija, a kada je legitimno korištenje promjene pravnog okvira na tržištu. Svakako bi trebalo izbjegavati i različite kriterije u različitim područjima (poput tržišnog natjecanja) za koje ne postoji osnova u Ugovorima, što je, na kraju krajeva, i temeljni cilj kodifikacije.

Važno je napomenuti da pravna osnova za kodifikaciju upravnog postupka pred tijelima Unije postoji. To je čl. 298. Ugovora o funkcioniranju Europske unije koji propisuje da u obavljanju svojih zadaća, tijela, institucije, agencije i uredi EU-a imaju potporu otvorene, učinkovite i neovisne europske administracije. Dalje je propisano da, u skladu s Pravilnikom o osoblju i Uvjetima zaposlenja usvojenima na temelju članka 336. Ugovora o funkcioniranju Europske unije, Europski parlament i Vijeće uredbama, u skladu s redovnim zakonodavnim postupkom utvrđuju odredbe u tu svrhu. Prema čl. 225. Ugovora, Europski parlament može, odlukom većine zastupnika, od Komisije zatražiti podnošenje odgovarajućeg prijedloga o pitanjima za koje smatra da ih je, radi provedbe Ugovora, potrebno urediti aktom EU-a. Eventualno odbijanje Komisija mora obrazložiti. Nažalost, čini se da će činjenica da Komisija ima isključivo pravo zakonodavne inicijative i dalje predstavljati zapreku kodifikaciji upravnog postupka pred tijelima Unije.

U pogledu autonomije država članica stvari su još kompleksnije. Praksa Suda EU-a pokazala je da načelo djelotvornosti prava EU-a u velikoj mjeri derogira nacionalne propise koji utječu na zaštitu legitimnih očekivanja, poput rokova za ukidanje upravnih akata povoljnih za stranku. Ovakvi problemi mogli bi se riješiti ujednačavanjem nacionalnih pravila upravnog postupka u situacijama u kojima državna tijela primjenjuju pravo EU-a. Pravna osnova za takvo ujednačavanje bi mogao biti čl. 114. Ugovora o funkcioniranju Europske unije koji propisuje da Europski parlament i Vijeće, odlučujući u skladu s redovnim zakonodavnim postupkom i nakon savjetovanja s Gospodarskim i socijalnim odborom, usvaja mjere za usklađivanje odredaba nacionalnih propisa, čiji je cilj uspostava i funkcioniranje unutarnjeg tržišta. Navedena 
odredba Ugovora se u prošlosti već dosta široko tumačila, gdje je postojanje potencijalnih zapreka funkcioniranju unutarnjeg tržišta EU-a u nacionalnom pravu bilo dovoljno za donošenje ujednačavajućih propisa od strane Unije. ${ }^{58}$ Različita postupovna pravila za ostvarivanje prava koja jamči zakonodavstvo Unije svakako bi mogla biti obuhvaćena ovakvim širokim tumačenjem. Naposljetku, tu je i čl. 352. Ugovora, kojim je propisano da, ako se u okviru politika utvrđenih Ugovorima pokaže da je potrebno djelovanje EU-a za postizanje jednog od ciljeva određenih Ugovorima (koji uključuju uspostavu unutarnjeg tržišta), a Ugovorima nisu predviđene potrebne ovlasti, Vijeće jednoglasno na prijedlog Komisije i uz prethodnu suglasnost Europskog parlamenta usvaja odgovarajuće mjere.

Ujednačavanje nacionalnih postupovnih pravila u predmetima u kojima se primjenjuje pravo EU-a može naravno biti problematično iz perspektive ustavnog prava država članica, zbog različitog tretiranja pojedinaca čiji predmeti ne spadaju u područje primjene europskog prava. Zato ono može potaknuti ujednačavanje općih nacionalnih pravila upravnog postupka. Uostalom, samo načelo zaštite legitimnih očekivanja se, zahvaljujući pravu EU-a, proširilo u opće propise država članica koji uređuju upravni postupak, tako da navedena dinamika ne bi predstavljala presedan. ${ }^{59}$ Posrijedi bi bio velik iskorak prema ujednačenom europskom upravnom pravu, o čemu bi se svakako u krugovima pravne struke trebalo dalje razgovarati.

\section{ZAKLJUČAK}

Zaštita legitimnih očekivanja predstavlja jedno od općih načela prava Europske unije koje se razvilo kroz desetljeća prakse sudova EU-a. Analiza navedene prakse ukazala je na više otvorenih pitanja koja uključuju, među ostalim, kada je zakonodavac EU-a vezan legitimnim očekivanjima stranaka koje je stvorilo prethodno, u međuvremenu izmijenjeno, zakonodavstvo Unije; u kojim situacijama prethodna upravna praksa stvara legitimna očekivanja; nelegitimnost očekivanja koja su nastala u spekulativne svrhe; razliku u pravnoj snazi protupravnih upravnih odluka i drugih postupanja uprave za nastanak legitimnih očekivanja. Navedena otvorena pitanja prvenstveno su proizvod nedosljednosti u sudskoj praksi te u nedostatku jasnog obrazloženja pojedinih odluka. Također se postavilo pitanje odnosa prava EU-a i autonomije država članica, vezano uz mogućnost da nezakoniti upravni akti stvore legitimna očekivanja te istek nacionalnog zakonskog roka za ukidanje nezakonitog rješenja kojim je stranka stekla neko pravo, u kojem slučaju se država članica ne može pozivati na nacionalna pravila upravnog postupka zbog povrede načela djelotvornosti prava EU-a.

Opisani problemi ilustriraju manjkavost trenutačnog pravnog uređenja s mnoštvom pravnih izvora te ukazuju na potrebu kodifikacije upravnog postupka pred tijelima Unije. Dosad je bilo više inicijativa za kodifikacijom, no bez uspjeha, mada pravna osnova u Ugovoru o funkcioniranju Europske unije postoji. Tako će i ostati dok Europska komisija ne iskoristi svoje (isključivo) pravo zakonodavne inicijative i predloži sekundarni kodifikacijski propis zakonodavcu EU-a.

58 Vidi Predmet C-380/03 Federal Republic of Germany $v$ European Parliament and Council of the European Union [2006] ECR I-11573 točka 41. 
Analiza ukazuje na to da bi buduća zakonodavna rješenja na razini Europske unije trebala onemogućiti da nezakoniti upravni akti stvaraju legitimna očekivanja, jer bi se tako izbjegle dvojbe koje postoje pri primjeni prava EU-a od strane upravnih tijela same Unije. Na taj način bi se otklonila i mogućnost različitog tretmana nezakonitih nacionalnih upravnih odluka koje praktički ne mogu stvoriti legitimna očekivanja. Nadalje, trebalo bi izbjegavati nejasne i gotovo arbitrarne situacije, odnosno postupanja. To se primjerice odnosi na isključenje legitimnosti očekivanja koja su nastala u spekulativne svrhe, budući da nije jednostavno odrediti kriterije kada je nešto spekulacija, a kada je legitimno korištenje promjene pravnog okvira radi ostvarenja tržišne prednosti. Trebalo bi izbjegavati i različite kriterije u različitim područjima za koje ne postoji osnova u Ugovorima. Vezano uz to, ne postoji razlog da prethodna učestala, dosljedna i zakonita upravna praksa u područjima poput tržišnog natjecanja ne može stvoriti legitimna očekivanja, dok u drugim područjima može. Naravno, u užim područjima koja su ostavljena na slobodno odlučivanje upravnom tijelu, poput izračuna sankcija, ograničavanje te slobode može imati štetan učinak i za javni interes i za prava samih stranaka. ${ }^{60}$ Takva uža područja potrebno je jasno odrediti propisima, kako bi se izbjegle nejasnoće.

Pitanja koja se javljaju u vezi s primjenom načela legitimnih očekivanja u kontekstu upravnih odluka tijela država članica koja primjenjuju pravo EU-a mogu se riješiti ujednačavanjem nacionalnih pravila upravnog postupka za takve situacije. Pravne osnove u Ugovorima također postoje, no takav postupak mogao bi stvoriti tenzije u ustavnim uređenjima država članica. U svakom slučaju, znanost i struka upravnog prava trebale bi i jačati raspravu u potrazi za optimalnim rješenjima u ovom bitnom području europskog prava.

\section{LITERATURA}

1. Arnull, A., The Principle of Effective Judicial Protection in EU law: an Unruly Horse?, European Law Review, god. 36, br. 1, 2011., str. 51.-70.

2. Barak-Erez, D., The Doctrine of Legitimate Expectations and the Distinction Between the Reliance and Expectation Interests, European Public Law, god. 11, br. 4, 2005., str. 583.-601.

3. Craig, P., De Burca, G., EU Law: Text, Cases and Materials, Oxford University Press, Oxford, 2015.

4. Crnić-Grotić, V., Sgardelli Car, N., Ljudska prava u Europskoj uniji u praksi Europskog suda u Luxembourgu, Zbornik Pravnog fakulteta u Zagrebu, god. 60, br. 5, 2010., str. 971.-994.

5. Đerđa, D., Pravila upravnog postupka u europskom pravu, Zbornik Pravnog fakulteta Sveučilišta u Rijeci, god. 33, br. 1, 2012., str. 109.-144.

6. Đerđa, D., Zaštita legitimnih očekivanja u upravnom pravu, Zbornik Pravnog fakulteta Sveučilišta u Rijeci, god. 34, br. 1, 2013., str. 83.-113.

7. Harbo, T.-I., The Function of the Proportionality Principle in EU Law, European Law Journal, god. 16, br. 2, 2010., str. 158.-185.

8. Jerčinović, A., Novi trendovi u kodifikaciji pravila upravnog postupka u Europskoj uniji, Hrvatska pravna revija, br. 3, 2018., str. 79.-84.

9. Kakouris, H. C., Do the Member States Possess Judicial Procedural "Autonomy"?, Common Market Law Review, god. 34, br. 6, 1997., str. 1389.-1412.

6o Za važnost ovih uvjeta vidi Đerđa, op. cit. u bilj. 1, str. 98. 
10. Kilpatrick, C., The Future of Remedies in Europe, u: Kilpatrick, C.; Novitz, T.; Skidmore, P., The Future of Remedies in Europe, Hart Publishing, Oxford, 2000.

11. Lenaerts, K., Gutman, K., "Federal Common Law" in the European Union: A Comparative Perspective from the United States, The American Journal of Comparative Law, god. 54, br. 1, 2006., str. 1.-121.

12. Lock, T., EU Accession to the ECHR: Implications for Judicial Review in Strasbourg, European Law Review, god. 35, br. 1, 2010., str. 777.-798.

13. Nicolaides, P., Geilmann, M., What is Effective Implementation of EU Law, Maastricht Journal of European and Comparative Law, god. 19, br. 3, 2012., str. 383.-399.

14. Omejec, J., Konvencija za zaštitu ljudskih prava i temeljnih sloboda u praksi Europskog suda za ljudska prava : strasbourški acquis, Novi informator, Zagreb, 2013.

15. Pescatore, P., The Context and Significance of Fundamental Rights in the Law of the European Communities, Human Rights Journal, god. 2, br. 6, 1981., str. 295.-308.

16. Schønberg, S., Legitimate Expectations in Administrative Law, Oxford University Press, Oxford, 2000.

17. Schwarze, J., European Administrative Law: Revised First Edition, Sweet \& Maxwell, London, 2006.

18. Selanec, G., Povelja temeljnih prava Europske unije, u: Rodin, S.; Ćapeta, T.; Goldner Lang, I., Reforma Europske unije: Lisabonski ugovor, Narodne novine, Zagreb, 2009.

19. Šikić, M., Ofak, L., Nova načela upravnog postupka (s posebnim naglaskom na razmjernost, legitimna očekivanja i stečena prava), Zbornik Pravnog fakulteta Sveučilišta u Rijeci, god. 32, br. 1, 2011., str. 127.-153.

20. Šikić, M., Zaštita pravne sigurnosti stranaka u upravnom postupku - pravomoćnost i legitimna očekivanja, Zbornik Pravnog fakulteta Sveučilišta u Rijeci, god. 35, br. 1, 2014., str. 147.-161.

21. Thomas, R., The Protection of Legitimate Expectations in UK Administrative Law, The Protection of Legitimate Expectations under Administrative Law, Bergen, 2012.

22. Vezmar Barlek, I., Primjena načela legitimnih očekivanja u praksi Upravnog suda Republike Hrvatske, Zbornik Pravnog fakulteta Sveučilišta u Rijeci, god. 32, br. 1, 2011., str. 569.-581.

23. Von Bogdandy, A., The European Union as a Human Rights Organization? Human Rights and the Core of the European Union, Common Market Law Review, god. 37, br. 6, 2000., str. 1307.-1338.

24. Yourow, H. C., The Margin of Appreciation Doctrine in the Dynamicy of European Human Rights Jurisprudence, Kluwer Law International, Den Haag, 1996.

\section{POPIS PROPISA, AKATA I SUDSKIH ODLUKA}

1. 89/665/EEZ: Direktiva Vijeća od 21. prosinca 1989. o usklađivanju zakona i drugih propisa u odnosu na primjenu postupaka kontrole na sklapanje ugovora o javnoj nabavi robe i javnim radovima [1989] Službeni list broj L395/33.

2. European Ombudsman, The European Code of Good Administrative Behavior, European Communities, Luxemburg, 2005.

3. Obavijest Komisije o oslobađanju od kazni i smanjenju kazni u slučajevima kartela [2006] Službeni list broj C298/17.

4. Povelja Europske unije o temeljnim pravima [2016] Službeni list, broj C202/389.

5. Predmet 6/64 Flaminio Costa v E.N.E.L. [1964] ECR 00585.

6. Predmet 29/69 Erich Stauder v City of Ulm - Sozialamt [1969] ECR 00419. 
7. Predmet 11/70 Internationale Handelsgesellschaft mbH v Einfuhr- und Vorratsstelle für Getreide und Futtermittel [1970] ECR 01125.

8. Predmet 4/73 J. Nold, Kohlen- und Baustoffgroßhandlung $v$ Commission of the European Communities [1974] ECR 00491.

9. Predmet 74/74 Comptoir national technique agricole (CNTA) SA v Commission of the European Communities [1975] ECR 00533.

10. Predmet 2/75 Einfuhr- und Vorratsstelle für Getreide und Futtermittel v C. Mackprang [1975] ECR 00607.

11. Predmet 54/77 Antoon Herpels v Commission of the European Communities [1978] ECR 00585.

12. Predmet 106/77 Amministrazione delle Finanze dello Stato v Simmenthal SpA [1978] ECR 00629.

13. Predmet 84/78 Ditta Angelo Tomadini Snc v Amministrazione delle finanze dello Stato [1979] ECR 01801.

14. Predmet 188/82 Thyssen AG v Commission of the European Communities [1983] ECR 03721.

15. Predmet 15/85 Consorzio Cooperative d'Abruzzo v Commission of the European Communities [1987] ECR 01005.

16. Predmet 265/85 Van den Bergh en Jurgens BV and Van Dijk Food Products (Lopik) BV v Commission of the European Communities [1987] ECR 01155.

17. Predmet 344/85 SpA Ferriere San Carlov Commission of the European Communities [1987] ECR 04435.

18. Predmet 120/86 J. Mulder v Minister van Landbouw en Visserij [1988] ECR 02321.

19. Predmet C-5/89 Commission of the European Communities $v$ Federal Republic of Germany [1990] ECR I-03437.

20. Predmet C-260/89 Elliniki Radiophonia Tiléorassi AE and Panellinia Omospondia Syllogon Prossopikou v Dimotiki Etairia Pliroforissis and Sotirios Kouvelas and Nicolaos Avdellas and others [1991] ECR I-02925.

21. Predmet C-313/90 Comité International de la Rayonne et des Fibres Synthétiques and others v Commission of the European Communities [1993] ECR I-01125.

22. Predmet C-284/94 Kingdom of Spain v Council of the European Union [1998] ECR I-07309.

23. Predmet C-183/95 Affish BVv Rijksdienst voor de keuring van Vee en Vlees [1997] ECR I-04315.

24. Predmet C-112/00 Eugen Schmidberger, Internationale Transporte und Planzüge v Republik Österreich [2003] ECR I-05659.

25. Predmet C-36/02 Omega Spielhallen- und Automatenaufstellungs-GmbH v Oberbürgermeisterin der Bundesstadt Bonn [2004] ECR I-09609.

26. Predmet C-380/03 Federal Republic of Germany v European Parliament and Council of the European Union [2006] ECR I-11573.

27. Predmet C-408/04 P Commission of the European Communities v Salzgitter AG [2008] ECR I-02767.

28. Predmet C-432/05 Unibet (London) Ltd, Unibet (International) Ltd v Justitiekanslern [2007] ECR I-02271.

29. Predmet C-517/15 P AGC Glass Europe and Others v European Commission ECLI:EU:C:2017:598.

30. Predmet Pine Valley Developments LTD and Others v Ireland (zahtjev br. 12742/87).

31. Predmet T-2/93 Société Anonyme à Participation Ouvrière Compagnie Nationale Air France v Commission of the European Communities [1994] ECR II-00323.

32. Predmet T-55/99 Confederación Española de Transporte de Mercancías (CETM) v Commission of the European Communities [2000] ECR II-03207. 
33. Predmet T-308/00 Salzgitter AG v European Commission [2004] ECR II-01933.

34. Predmet T-233/16 P José Luis Ruiz Molina v European Union Intellectual Property Office ECLI:EU:T:2017:435.

35. Pročišćena verzija Ugovora o Europskoj uniji i Ugovora o funkcioniranju Europske unije [2016] Službeni list, broj C202/1.

36. Research Network on EU Administrative Procedure, ReNEUAL Model Rules on EU Administrative Procedure, 2014.

37. Rezolucija Europskog parlamenta o otvorenoj, učinkovitoj i neovisnoj upravi Europske unije, (2016/2610(RSP)).

38. Spojeni Predmeti 7/56 i 3/57 do 7/57 Dineke Algera, Giacomo Cicconardi, Simone Couturaud, Ignazio Genuardi, Félicie Steichen v Common Assembly of the European Coal and Steel Community [1957] ECR 00039 .

39. Spojeni Predmeti 36/59 do 38/59 i 40/59 Präsident Ruhrkolen-Verkaufsgesellschaft mbH, Geitling Ruhrkohlen-Verkaufsgesellschaft mbH, Mausegatt Ruhrkohlen-Verkaufsgesellschaft mbH and I. Nold KG $v$ High Authority of the European Coal and Steel Community [1960] ECR 00423.

40. Spojeni Predmeti Dansk Rørindustri A/S (C-189/02 P), Isoplus Fernwärmetechnik Vertriebsgesellschaft mbH and Others (C-202/02 P), KE KELIT Kunststoffwerk GmbH (C-205/02 P), LR af 1998 A/S (C206/02 P), Brugg Rohrsysteme GmbH (C-207/02 P), LR af 1998 (Deutschland) GmbH (C-208/02 P) and ABB Asea Brown Boveri Ltd (C-213/02 P) v Commission of the European Communities [2005] ECR I-05425.

41. Spojeni Predmeti T-60/06 RENV II i T-62/06 RENV II Italian Republic v European Commission ECLI:EU:T:2016:233.

42. Spojeni Predmeti T-233/11 i T-262/11 Hellenic Republic and Ellinikos Chrysos AE Metalleion kai Viomichanias Chrysou v European Commission ECLI:EU:T:2015:948.

43. U-IIIB-4366/2005 od 5. travnja 2006.

44. Zakon o općem upravnom postupku, Narodne novine, broj 47/2009. 


\section{THE PRINCIPLE OF THE PROTECTION OF LEGITIMATE EXPECTATIONS IN THE ADMINISTRATIVE LAW OF THE EUROPEAN UNION AND LEGAL AUTONOMY OF THE MEMBER STATES}

\section{Summary}

Protection of legitimate expectations is a general principle of European Union law that has been developed through the case-law of the Court of Justice of the European Union. There are several unresolved issues that have been pointed out by the analysis of the said case-law. These are inter alia: When is the European Union legislator bound by legitimate expectations generated by a preceding piece of (changed) legislation, when does the preceding administrative practice generate legitimate expectations; the issue of the lack of legitimacy in case of speculative activities, the issue of differentiation between unlawful decisions and unlawful representations in generating legitimate expectations. Other issues concern the relation between the European Union law and the Member States' legal autonomy concerning the possibilities for unlawful administrative acts to generate legitimate expectations and the expiration of the time-period prescribed by national law for revocation of unlawful administrative decisions beneficial for a party concerned. In the latter case, a Member State may not plead national administrative rules in order to justify its failure to comply with the principle of effectiveness of European Union law. The aim of this paper is to analyse these issues and determine whether the regulatory framework of the European Union can be improved in order to avoid potential problems in practice. The analysis is based on the case-law of the Court of Justice of the European Union and legal acts of the European Union along with Croatian and foreign literature on administrative, constitutional and European law.

These issues illustrate the deficiencies of the current legal framework of the European Union with a number of applicable legal sources and ate the same time they emphasise the need for a codification of administrative procedure on the Union level. There have been several initiatives in this respect but with no real effect, even though there is a legal basis for such an endeavour prescribed by the Treaty on the Functioning of the European Union. Such a codification should prohibit unlawful administrative acts from generating legitimate expectations. This would also resolve the issue of different treatment of national administrative decisions that may not generate legitimate expectations. Furthermore, unclear and arbitrary interpretations should be avoided, as in the case of speculative activities the existence of which is not easy to determine. Finally, application of different criteria in different areas of law should be avoided if there is no basis therefor in the Treaties.

Keywords: $\quad$ Legal autonomy of the Member States, legitimate expectations, general principles of law, Court of Justice of the European Union, administrative act, administrative law of the European Union

\section{(c) (1) (8)}

This work is licensed under a Creative Commons

Attribution-NonCommercial 4.0 International License.

Tomislav Sokol, PhD, titular Assistant Professor at Catholic University of Croatia, senior lecturer, Zagreb School of Economics and Management, Jordanovac 110, 10000 Zagreb, Republic of Croatia. Email address: tsokol@zsem.hr. ORCID: http://orcid. org/0000-0002-3592-2967. 